\title{
電気的漏水位置検知にしや水シートの 電気特性が与える影響
}

\author{
荒井 健 $1 \cdot$ 新井 斉 $2 \cdot$ 山崎 宣悦 $3 \cdot$ 大即 信明 4 \\ ${ }^{1}$ 正会員 前田建設工業株式会社 土木設計部 （T179-8903 東京都練馬区高松 5 丁目 8 番 J.CITY） \\ 2 光が丘興産株式会社 営業部 (テ179-0075 東京都練馬区高松 5 丁目 8 番 J.CITY) \\ ${ }^{3}$ 株式会社レイディック（テ202-0022 東京都保谷市柳沢 2-17-20） \\ ${ }^{4}$ 正会員 工学博士 東京工業大学 開発システム工学科（テ152-8552 東京都目黒区大岡山 2-12-1）
}

\begin{abstract}
管理型廃㲤物最終処分場に敖設された合成樹脂や合成ゴムのしや水シートの電気的漏水検知システムの 研究が広く行われるようになった.これらの電気的漏水検知システムは, 電位差や電流および電気抵抗の 測定で漏水の周辺に生ずる電気的な異常をとらえることによっている.こうした測定システムのすべては, しゃ水シートの有する高い絶縁抵抗を前提としている. しかしながら, 各種しや水シートの電気特性を調 べてみると，絶縁体とはいえないものもあり，測定の前提条件が必ずしも成立していない，本論文は，管 理型廃牽物処分場の電気特性を踏まえた上で, 各種しや水シートの電気特性を検証し, 電気的漏水位置検 知システムの測定結果に与える影響について述へる。.
\end{abstract}

Key Words: landfill site, geomembrane, leak detection, resistivity, phase

\section{1.はじめに}

廃棄物処分場の建設計画を立案する場合，廃棄 物処分場が周辺住民にとって迷惑施設の性格が強 いため, 人口密度の低い山間部立地となることが 多い.こうした廃棄物処分場建設が計画される山 間部は, 飲料水や農業用水の水源地と重なること も多い。このような立地条件における管理型廃棄 物処分場でしゃ水シートに損傷する事故が生じた 場合, 廃棄物中の有害物質が溶出した浸出水が地 下水に漏洩し飲料水や農業用水が污染される危険 がある．従来から，処分場のモニタリング施設と して観測井戸の設置が義務づけられているが，地 下水の水質検查により浸出水の漏洩が確認された 段階では，污染が広範囲に拡がり，環境の修復に 多くの経費や時間が必要となる。したがって，こ のような周辺環境に污染が拡散する前に, 破損し たしゃ水シートの漏水発生位置を早期に特定し早 急に補修しなければならない.

現状におけるしゃ水シートの漏水位置検知方法 の主なものに, 2 重化したしゃ水シート間に流入 してくる浸出水や 2 重化したしや水シートの気密 性から漏水を検知する方法 ${ }^{1)-3)}$ と電位異常や低比
抵抗ゾーンなどから漏水を検知する ${ }^{4)-16)}$ 電気的手 法がよく知られている.これらの方法のうち， 2 重化したしゃ水シートを利用して漏水を検知する 方法は, しや水シートから流出する浸出水を直接 検知するため, 漏水の規模や緊急性を直接判断で きる利点があるが, 漏水位置をゾーンでしか判断 できない欠点がある。

一方, 電気的手法の場合, 漏水位置を座標とし て知ることができるが，実際の漏水の規模は処分 場の降水量に処分場からの浸出水流出量と蒸発に よる損失量や処分場内の貯留量の収支計算から間 接的にしか知ることができない。しかし，廃棄物 の埋立作業などにともなう事故で生じたしゃ水シ 一トの損傷や施工不良部分を検知して, 早急に対 策がとれる電気的手法のメリットは非常に大きく， 技術革新により精度向上や経済性の向上が十分可 能であり今後の発展性に優れると判断される。 こ うした電気的手法のメリットから, 種々の電気的 漏水位置検知システムが開発されている.

それらの電気的漏水位置検知システムは, すべ てしゃ水シートの有する高い電気抵抗を利用して 漏水位置を検知している. しかしながら, 処分場 に敷設されるしゃ水シートの電気特性を踏まえた 
漏水位置検知システムの研究はほとんどみられな い，そこで，本論文は廃衰物処分場の電気的モデ ルと, 各種しゃ水シートの電気特性ならびにそれ に付随して発生する測定障害について述べるもの である。

\section{2. 既往の電気的漏水位置検知方法の研究}

高導電率の板状鉱体の探査に，鉱体に直接電流 を流し，鉣体の賦存状況を反映した電位分布のひ ずみから鉱体の規模，深度，広がりを知る鉱体流 電法 ${ }^{17)}$ が用いられている。この手法を応用して, 処分場内外に電圧を印加し，処分場内に多数設置 した電位測定電極で測定した電位分布の乱れから 漏水位置を検知する漏水位置検知方法の研究が古 くから実施されている ${ }^{4)}$. 日本においても鉱体流 電法による漏水位直検知方法 ${ }^{5), 6)}$ とこの改良技術 について研究されている．鉱体流電法は，非常に 簡便な装置を使用するだけで，漏水位置を検知で きる利点があるが，地盤や廃棄物の電気的特性に より等電位線の間隔が乱れたり, 精密な測定を行 う場合には自然電位を別個に測定して，その結果 を鉱体流電法の測定結果から差し引く操作が必要 となる.

こうした鉱体流電法単独で使用した場合の不具 合に対して，島らは，処分場内の比抵抗分布を別 個に測定することにより, 漏水部分から流れる電 流の大きさを評価する手法を提案している ${ }^{7)}$. し かし, この方法は, 電位分布の他に比抵抗分布を 別個に測定する必要があるため, 計測に要する時 間が非常に長くなる欠点がある.

このほか, 廃棄物の影響を受けない 2 重化した しゃ水シートの排水層に線電極を格子状に設置し, 電位を測定する手法 ${ }^{8)}$ も提案されているが， 2 重 化したしゃ水シートの排水層内が浸出水で充満し た場合に測定が困難となる。このような 2 重化し たしや水シートの排水層という電気的にばらつき の少ない部分に電極を配置する方法は，鉱体流電 法だけでなく低比抵抗ゾーンを検出することによ り漏水を検知する方法 ${ }^{91,10)}$ にもみられるが，流入 した浸出水で排水層内が充満した場合に同様の測 定上の問題がある.

これらの他に，電位傾度法 ${ }^{18)}$ を応用した方法も

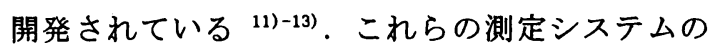
うち電位測定電極だけでなく印加電極も同時にス キャンしていく測定方法 ${ }^{13)}$ は，印加電圧を低く抑 えることにより電極からの電界の広がりを小さく
し, 埋め立てられる廃棄物の電気特性の影響を受 けにくいことと, 測定電極の設置面の裹面側に線 電極を等間隔に設置して電流が流れやすく低電圧 で十分測定が可能としている点に新規性がある.

さらにしゃ水シート裏面側の電位を均一にするた めにアルミ䇴を用いた面電極を設置し，しゃ水シ ートの表面側に設けた点電極間と面電極間のイン ピーダンス分布から漏水を検知する方法 ${ }^{14)}$ も研究 されている.

その他に, 電流を測定することにより漏水を検 知する方法として, しゃ水シートの上下に線電極 を直交するように配置することで少数の測定電極 で漏水位置を検知する方法 ${ }^{15)}$ や, 印加電極から等 距離の位置に流れる電流の大きさを比較すること により漏水位置を検知する測定方法 ${ }^{16)}$ も開発され ている.

このように電気的漏水位直検知に関する種々の 研究がなされているが, 処分場の電気的特性を支 配するしや水シートの電気特性を踏まえた実験 ${ }^{13)}$ はわずかである。

\section{3. 処分場の電気特性}

信号処理の精度向上技術として, 特性が明確な 信号を発信し，ノイズが混入した受信側の入力信 号から発信信号の特性に基づいて有用な情報のみ 抽出する手法が広く用いられている ${ }^{19)}$. 処分場の 電気的漏水位置検知においても, 処分場やしゃ水 シートの電気特性を十分把握した上で, 前述の信 号処理技術を用いれば高精度の漏水位置検知が期 待できる、筆者らは, このような測定精度向上技 術をふまえると, 周期や位相が明確な交流電源が 電気的漏水位置検知に有利と判断する. 以下に処 分場に交流電圧を印加した場合の電流の特性と, 処分場の電気特性を左右するしゃ水シートの特性 について述べる.

\section{（1）処分場の等価回路モデル}

図ー1のように，最近では廃棄物処分場にしゃ 水シートが 2 重に敷設されるようになった。こう した処分場の廃衰物側の第 1 層しや水シートに漏 水があり，処分場の第 1 層しゃ水シート上の電極 と排水層内の電極間に交流電圧を印加した場合に ついて考える.

電気的漏水位置検知システムでは, 既往の電気 的漏水位置検知方法の研究において示したように， 電気抵抗の大きいしゃ水シートに生じた損傷や施 


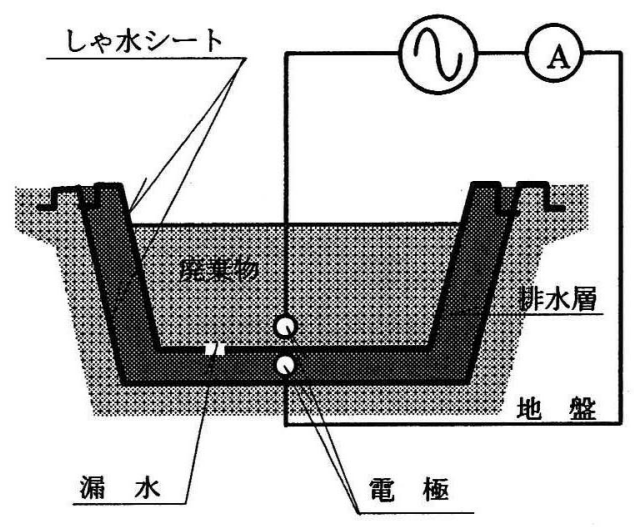

图ー1 第 1 層しゃ水シートに漏水がある処分場

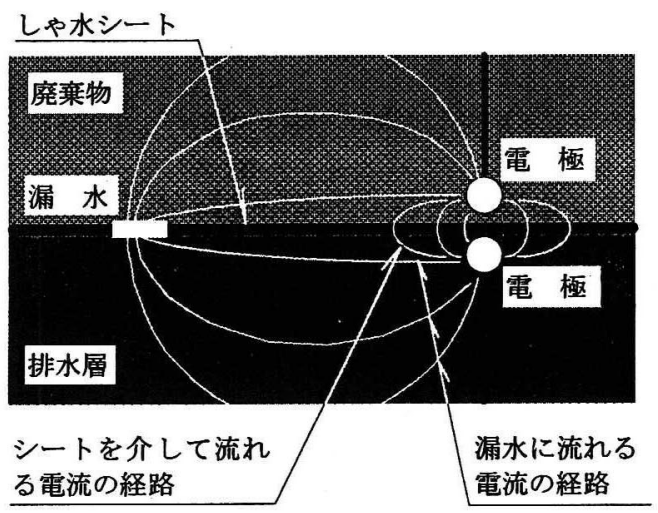

図一２処分場に流れる電流の経路

工不良部周辺に生ずる電気的な異常を検知するこ とによっており，検知される漏水箇所には必然的 に浸出水が漏れていないものも含まれる.

第 1 層のしゃ水シートの漏水と電極周辺の電気 の流れは，図一2に示すようにしゃ水シートを介 して流れる電流と廃棄物と漏水箇所と排水層を経 由して流れる電流に大別できる. しや水シートを 介して流れる電流は, 電流が廃棄物や排水層に流 れる過程で電圧降下をきたすため, それぞれの電 極の近傍で流れる割合が最も大きいと考えられる. 一方，しや水シートの漏水部分を流れる電流も， 電極から大きく拡がる電気の経路のうち最も電気 抵抗が小さい経路を主に流れるものと考えられる.

ここで, しゃ水シートを介して流れる電流の経 路のうち, 廃棄物の電気抵抗を $R_{\text {FS }}$ とし, 排水層 の電気抵抗を $R_{D S}$ とし, しゃ水シートの静電容量 を $C$ とする. また，漏水を経由して流れる電流の 経路のうち, 漏水の大きさに相当する電気抵抗を

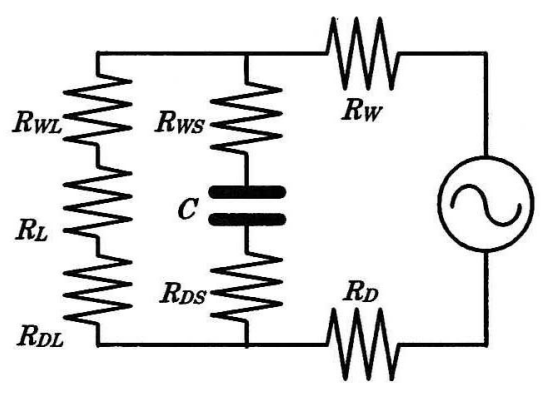

図一3 膤水のある処分場の等価回路

$R_{L}$ とし, 廃萧物の電気抵抗を $R_{M L}$ とし, 排水層の 電気抵抗を $R_{D L}$ とする.ささらに, 漏水を経由して 流れる電流としゃ水シートを介して流れる電流の 廃棄物と排水層における共通の電流経路の電気抵 抗を $R$,と $R_{D}$ で表記する. 以上のパラメータを用 いて, 処分場の電気的特性は模式的に図一 3 等 価回路に示される ${ }^{20)}$.この等価回路において，そ れぞれのパラメータの值は, 電極と漏水までの距 離や埋め立てられた廃棄物の種類や覆土ならびに 排水層の比抵抗によって処分場内の各位置で異な ると考えられる.こうした埋め立てられる廃棄物 や覆土の電気特性の影響をなるべく受けないよう に, 既往の電気的漏水位置検知方法では, しゃ水 シートの近傍に測定電極を配置したり，比抵抗分 布が均一な材料を敷設した排水層内に測定電極を 配置して対処している.

ところで, 图一ろの等価回路は, 交流電源を使 用した場合について示したが，図ー3の等価回路 は, 電源に完全な直流電源を使用した場合にも普 遍的に成り立つ.すなわち，漏水位置検知に完全 な直流電圧を処分場に印加した場合には，しゃ水 シートの静電容量限界まで帯電する過渡現象時以 降は, しや水シートの電気特性は完全な絶縁体で あるから，この部分の回路を無視して考えればよ く, 電気回路の考え方として非常に単純となる. しかし，一般に電気探查において，完全な直流電 圧が印加されることは少なく，交替直流と称する 矩形波電圧を印加しており, 厳密な意味での直流 電圧を使用していない，ここで，波高が 1 で，角 周波数 $\omega$ の矩形波 $f(t)$ は, 時間を $t$ としてフーリ 工級数展開で式(1)で示される ${ }^{21)}$.

$$
f(t)=\sum_{i=1}^{\infty} \frac{4}{(2 i-1) \pi} \sin ((2 i-1) \omega t)
$$

式(1)からわかるように, 矩形波は各種角周波 数の交流電圧の重ね合わせである.ここで, 波高 


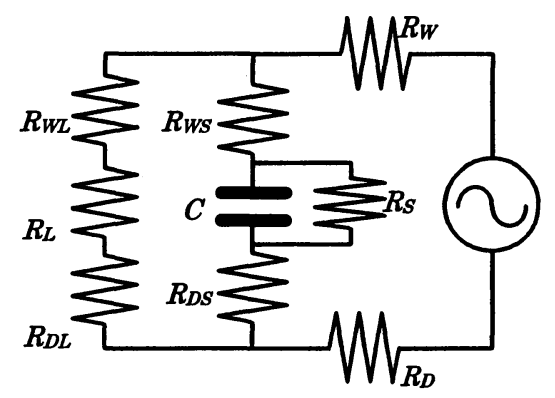

図-4 漏水が困難な処分場の等価回路

が 1 の矩形波電圧 $v(=f(t))$ が印加されたしゃ 水シート面に帯電する電荷 $q$ は, しゃ水シートの 静電容量 $C$ を用いて式(2)で示される.

$$
q=C v=C \sum_{i=1}^{\infty} \frac{4}{(2 i-1) \pi} \sin ((2 i-1) \omega t)
$$

しゃ水シートを介して流れる電流 $i$ は, 式(2)に 示すしや水シートに帯電する電荷 $q$ の時間微分値 となる.

$$
i=\frac{d q}{d t}=C \sum_{i=1}^{\infty} \frac{4 \omega}{\pi} \cos ((2 i-1) \omega t)
$$

式(3)から，しゃ水シートを介して流れる電流 成分が発生することがわかる.

こうした種々の電気的漏水位置検知方法におい て，図ー4に示すようにしゃ水シート自体に無視 できない大きさの電流が流れる電気抵抗成分 $R_{S}$ が あると, しゃ水シートの漏水部分に流れる電流と 区別不能な電流が流れ，漏水位置検知に大きな障 害となることがわかる.

\section{（2）しゃ水シートの厈みと角周波数}

ところで, 図一3の等価回路のしゃ水シートを 介して流れる回路と漏水を経由して流れる回路が 並列になっている部分において，しゃ水シートを 介して流れる回路のインピーダンス $\left(Z_{s}\right)$ は, 複素記号 $j$ を用いて 式(4)となり，その大きさ $\left(\left|Z_{s}\right|\right)$ は，式(5)に示すとおりとなる。一方， 漏水を流れる回路のインピーダンス $\left(Z_{L}\right)$ は, 式(6)に示すとおりとなる.

$$
Z_{S}=R_{W S}+R_{D S}-j \frac{1}{\omega C}
$$

$$
\begin{aligned}
& \left|z_{S}\right|=\sqrt{\left(R_{W S}+R_{D S}\right)^{2}+\left(\frac{1}{\omega C}\right)^{2}} \\
& z_{L}=R_{W L}+R_{L}+R_{D L}
\end{aligned}
$$

式(5)において, 廃車物と排水層の電気抵抗は, 電極位膡が固定されていれば一定值であるから， しゃ水シートを介して流れる電流は, 静電容量 （C）と角周波数 $(\omega)$ の積 $(\omega C)$ の大きさに よって決まることがわかる. したがって，しゃ水 シートを介して流れる電流を最低限におさえるた めには, 静電容量 $(C)$ と角周波数 $(\omega)$ をでき るだけ小さくすればよいことがわかる。しかし， 直流電源を使用した場合が角周波数の最小值 0 $(\mathrm{rad} / \mathrm{sec})$ に相当するが，前述のように測定值に 自然電位の影響で誤差が混入し，自然電位の影響 を別個に測定し差し引く操作が必要となる ${ }^{22)}$. ま た, 漏水を流れる回路のインピーダンスは, 式 (6) に示すように抵抗成分により構成されており，漏 水に流れる電流としゃ水シートを介して流れる電 流は位相が異なることがわかる。

ここで, 静電容量 $(C)$ は，しゃ水シート数設 面積 $(S)$ ， しゃ水シートの厚み $(d)$ ，真空の 誘電率 $\left(\varepsilon_{0}\right)$, 絶縁体の比誘電率 $(\varepsilon)$ を用いて 式 (7)に示される.

$$
C=\varepsilon_{0} \varepsilon \frac{S}{d}
$$

式 (7)により，しゃ水シートを介して流れる電 流は，廃暂物でおおわれた面積が広くかつしゃ水 シートが薄い程大きく，またしや水シート材料の 比誘電率が高い程大きくなることがわかる．しか し, 式(5) からしゃ水シートを介して流れる電流 は，( $(\omega C)$ の大きさに支配されているから，し や水シートの厚みが薄く静電容量 $C$ が大きい場合 には，角周波数を小さくしてしゃ水シートを介し て流れる電流を制御できることがわかる.

\section{4. 各種しや水シートの電気特性}

処分場に交流電圧を印加した場合，しゃ水シー トの静電容量に応じて流れる電流成分が生ずるこ とは前章で述べたとおりである。こうしたしゃ水 シートの静電容量に応じて流れる電流は, 漏水を 経由して流れる電流の位相と異なるため, 位相検 
表一 1 各種しゃ水シートの電気的特性

\begin{tabular}{|c|c|c|c|}
\hline 種 類 & $\begin{array}{c}\text { 電気抵抗 } \\
\left(M \Omega / 120 \mathrm{~cm}^{2}\right)\end{array}$ & $\begin{array}{c}\text { 静電容量 } \\
\left(\mathrm{nF} / 120 \mathrm{~cm}^{2}\right)\end{array}$ & $\begin{array}{l}\text { 電極 } \\
\text { 状態 }\end{array}$ \\
\hline \multirow{2}{*}{$\begin{array}{c}\text { E P DM } \\
\text { (A 社) }\end{array}$} & $8.5 \times 10^{-2}$ & 20.71 & 乾燥 \\
\hline & $5.4 \times 10^{-4}$ & 3150. & 湿潤 \\
\hline \multirow{2}{*}{$\begin{array}{l}\text { E P DM } \\
\text { (B 社) }\end{array}$} & 1.54 & 8. 22 & 乾燥 \\
\hline & 1. $1 \times 10^{-2}$ & 1270. & 湿潤 \\
\hline \multirow{2}{*}{$\begin{array}{l}\text { E P DM } \\
\text { (C 社) }\end{array}$} & 0.60 & 7.89 & 乾燥 \\
\hline & 3. $44 \times 10^{-3}$ & 1200. & 湿润 \\
\hline \multirow{2}{*}{$\begin{array}{c}\text { HD P E } \\
\text { (D社) }\end{array}$} & 10 以上 & 1.58 & 乾燥 \\
\hline & 10 以上 & 1.91 & 湿润 \\
\hline \multirow{2}{*}{$\begin{array}{c}\text { HD P E } \\
\text { (E 社) }\end{array}$} & 10 以上 & 2.76 & 乾燥 \\
\hline & 10 以上 & 3. 30 & 湿润 \\
\hline \multirow{2}{*}{$\begin{array}{l}P \text { V C } \\
(F \text { 社) } \\
\end{array}$} & 10 以上 & 1.28 & 乾燥 \\
\hline & 10 以上 & 1.55 & 湿润 \\
\hline \multirow{2}{*}{$\begin{array}{c}\text { 融着ゴム } \\
\text { (G社) }\end{array}$} & 10 以上 & 0.97 & 乾燥 \\
\hline & 10 以上 & 1.15 & 湿潤 \\
\hline \multirow{2}{*}{$\begin{array}{c}\text { 融着ゴム } \\
\text { (H社) }\end{array}$} & 10 以上 & 2. 39 & 乾燥 \\
\hline & 10 以上 & 2.66 & 湿润 \\
\hline \multirow{2}{*}{$\begin{array}{c}\text { 融着ゴム } \\
\text { ( I 社) }\end{array}$} & 10 以上 & 1.47 & 乾燥 \\
\hline & 10 以上 & 1.70 & 湿润 \\
\hline \multirow{2}{*}{$\begin{array}{c}\text { 導電性 HDPE } \\
\text { ( } \mathrm{J} \text { 社) }\end{array}$} & 10 以上 & 1.87 & 乾燥 \\
\hline & 10 以上 & 2.05 & 湿润 \\
\hline \multirow{2}{*}{$\begin{array}{l}\text { 非加硫ゴム接 } \\
\text { 着材 (A 社) }\end{array}$} & 10 以上 & 1.51 & 乾燥 \\
\hline & 10 以上 & 1.70 & 湿润 \\
\hline
\end{tabular}

波回路 ${ }^{18)}$ などを使用することにより分離可能であ る. しかし，図一 4 の $R_{S}$ に相当するしゃ水シート の電気抵抗成分に流れる電流の位相は, 漏水を経 由して流れる電流の位相と同相となるため, これ を分離することはできない. したがって，本章で はしゃ水シートの電気抵抗を中心に議論を進める こととする.

\section{（1）しゃ水シートの電気抵抗}

従来から一般廃畗物処分場向けとして E P D M (エチレン・プロピレン・ディエンモノマー) し や水シートが一般的なしや水材料として使用され， 最近ではHDPE（ハイデンシティーポリエチレ ン=高密度ポリエチレン) しゃ水シートなど熱融 着が可能な各種しゃ水シートが使用されるように なってきた. 一方, 産業廃畗物処分場向けのしゃ 水シートとして, P V C (ポリビニルクロライド =塩化ビニル）しや水シートも広く使用されてき た. しゃ水シートの厚みも一般に $1.5 \mathrm{~mm}$ 以上のも のが普通である. E P D M や水シートには，し
や水シートの接合に接着によるものと熱融着によ るものがある.ここではE P DMしゃ水シートと は, P V CやHD P Eしや水シートのように熱融 着ができず，接着剤などでしか接合できない製品 のみに限定する．また，熱融着が可能なタイプの E P D M や水シートを融着ゴムとして分類する.

各種しゃ水シートの電気特性は, 2 枚の厚さ $2 \mathrm{~mm}$ で $8 \mathrm{~cm} \times 15 \mathrm{~cm}$ の銅板の間にサンプルを挟み込み, $15 \mathrm{~kg}$ のウェイトが均等にかかるようにした状態で, $100 \mathrm{~Hz}$ の交流電圧を印加することによりもとめた. この実験において，供試体のしゃ水シートと銅板 の電極間の接触状態を改善するために電極表面を 水道水で湿潤状態にした測定と，電極の表面を乾 燥状態にした測定を実施した。試験に使用したし や水シートの厚みは, すべて $1.5 \mathrm{~mm}$ の製品である.

表一 1 に各種しや水シートの電気特性を示す. 表ー1から，E P D M, H D P Eおよび P V Cし や水シートをそれぞれ比較すると，E P D M ゃ 水シートの電気抵抗がそれ以外のしゃ水シートと 比較して非常に小さいことがわかる.また， E P DMしゃ水シートの静電容量は, 電極表面を湿潤 状態にした場合，桁違いに大きいことがわかる. 特に A 社のE P D M いゃ水シートの電気特性は, 電極表面が乾燥した条件で電気抵抗が $8.5 \times 10^{-2} \mathrm{M}$ $\Omega / 120 \mathrm{~cm}^{2}$, 静電容量が $20.71 \mathrm{nF} / 120 \mathrm{~cm}^{2}$ であっ た.

これに対し，P V CやHD P E しゃ水シートの 電気特性は電気抵抗が $10 \mathrm{M} \Omega / 120 \mathrm{~cm}^{2}$ 以上（直流 のテスターで計測した結果では，280〜 200M $\Omega /$ $120 \mathrm{~cm}^{2}$ 以上) であり, 静電容量が約 $1.5 \mathrm{nF} / 120 \mathrm{~cm}^{2}$ である。

P V CやHD P E のしゃ水シートは, 電極とし や水シートの接触状態が湿潤であっても電気抵抗 の特性はテスターの測定限界を超える大きな電気 抵抗であるが，E P D Lしゃ水シートの場合には $5.4 \times 10^{-4} \mathrm{M} \Omega / 120 \mathrm{~cm}^{2}$ と電気抵抗が非常に小さく なる. すなわち, 処分場のしや水シートの保護砂 が湿潤状態にある場合にはA社のE P D Uしゃ水 シートの有する電気抵抗は大きめに見積もっても P V C PHD P E しゃ水シートの 1 万分の 1 程度 と考えられる.

こうしたしゃ水シートの電気抵抗の違いは, し や水シート素材に含有されているカーボンブラッ クの多骞が影響しているものと考えられる.すな わち, P V C H P E のカーボンブラック含有 量は一般に $2 \%$ 程度であるのに対し，E P D M カーボンブラックの含有量は約 $30 \%$ であり，これ がしゃ水シートの電気抵抗に関与しているものと 
表一2 導電性 HDPE しや水シートの電気抵抗

\begin{tabular}{|c|c|c|}
\hline $\begin{array}{c}\text { しゃ水シートの } \\
\text { 種類 }\end{array}$ & 電気抵抗 $(M \Omega / 30 \mathrm{~cm})$ & 電極状態 \\
\hline $\begin{array}{c}\text { 導電性 H D P E } \\
\text { (導電性側) }\end{array}$ & $5.9 \times 10^{-3}$ & 乾燥 \\
\cline { 2 - 3 } & $5.8 \times 10^{-3}$ & 湿润 \\
\hline $\begin{array}{c}\text { 導電性 H D P E } \\
\text { (非導電性側) }\end{array}$ & 10 以上 & 乾燥 \\
\hline E P DM & 10 以上 & 湿润 \\
\hline (A 社) & $37 \times 10^{-3}$ & 乾燥 \\
\hline 融着 ゴム & $34 \times 10^{-3}$ & 湿润 \\
\cline { 2 - 3 } (H社) & 10 以上 & 乾燥 \\
\cline { 2 - 3 } & 10 以上 & 湿润 \\
\hline
\end{tabular}

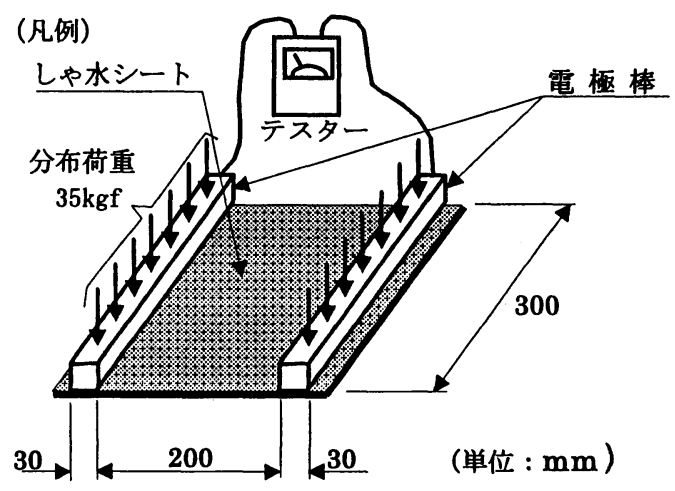

考えられる。

一方, 融着ゴム製しや水シートの電気特性は, P V C しゃ水シートやHD P E しゃ水シートの電 気特性と比較してほぼ同等の特性を示す。この理 由は, 融着ゴム製しゃ水シートは, ポリエチレン やポリプロピレンの混合物（カーボンブラック含 有量約 $2 \%$ ）にE P DMの粒子が分散した構造に なっているためと考えられる. したがって, 各社 の融着ゴム製しゃ水シートは，一般にE P DMと 称して販売されているが, 電気的特性からみると, H D P E P P V Cなどのプラスチックのしゃ水シ 一トと同様な特性を有していることがわかる.

しかし, 電気抵抗が大きい合成樹脂系のしや水 シートであっても, 配合される材料中に導電性の 高いカーボンブラックなどの材料が多く含まれて いれば, 電気抵抗は非常に小さくなる. 表一1の 導電性HD P E の欗に示したしゃ水シートは, 積 層構造をなしており, 廃棄物が埋め立てられる側 の表層を白色の顔料により着色して太陽熱の吸収 を低減し，地盤側の表層のカーボンブラック含有 量を約 $20 \%$ に増やして, 電気抵抗を小さくした製 品である.このしゃ水シートの敷設工事において, しゃ水シートの電気抵抗が小さい面とワイヤーブ
ラシ間に高電圧を印加し，白色のしゃ水シート表 面をワイヤーブラシでなで，スパークが飛ぶ箇所 から施工不良部やしゃ水シートのピンホール部分 を検知し，しゃ水シート敷設工事時の品質管理に 使用されている.

この製品のしゃ水シート表裏間の電気抵抗は, 表ー 1 に示すように通常のHD P E P P V C しゃ 水シートのように非常に大きい。 しかし，表一2 の凡例の図に示すようにカーボンブラック含有量 を增やした側の表面に 2 本の棒状電極（長さ $300 \mathrm{~mm}$ ）の間隔を $200 \mathrm{~mm}$ にして電気抵抗を測定す ると, $5.8 \times 10^{-3} \mathrm{M} \Omega / 30 \mathrm{~cm}$ となる.一方, 同様の 測定をE P DMしゃ水シートについて行うと， 34 $\times 10^{-3} \mathrm{M} \Omega / 30 \mathrm{~cm}$ となり, 導電性HDP E しや水シ 一トの電気抵抗は, E P D L 水シートの約 1 / 6 にすぎないことがわかる. 同様の測定を, 融 着ゴムや導電性H D P E しや水シートの白色に着 色された電気抵抗の大きいしゃ水シート面につい て行うと, 測定器の限界以上である $10 \mathrm{M} \Omega / 30 \mathrm{~cm}$ 以上の値を示す.

以上の測定結果から，しゃ水シートに含まれる カーボンブラックの含有量によって電気抵抗は大 きく変わることがわかる.

\section{（2）しゃ水シートと地盤の電気抵抗の比較}

地盤と A 社のE P D L や水シートの電気抵抗 について，図一 5 に示す土槽を用いて検討した. 土槽の大きさは, $19 \mathrm{~m} \times 9 \mathrm{~m}$ の平面形状で, しゃ水 シート上下に $\phi 3.2 \mathrm{~mm}$ の裸銅線を $2 \mathrm{~m}$ 間隔で設直 し, しゃ水シート上には厚さ $25 \mathrm{~cm} \sim 50 \mathrm{~cm}$ の砂層 を設けたものである。この形状の土槽をそれぞれ 隣接させて 2 つ造成し，1つの土槽には $\mathrm{A}$ 社製 $1.5 \mathrm{~mm}$ 厚のE P D M や水シートを敷設し, 他の 1 つの土槽には F 社製 $1.5 \mathrm{~mm}$ 厚の P V C しゃ水シ 一トを敷設した. 砂は, 同一の種類を使用し, 含

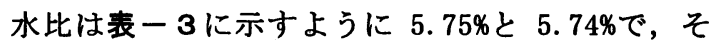
れぞれの土槽ともほぼ同一であった。

土槽に設置したしゃ水シート上下それぞれの電 極間電気抵抗を表一 4 に示す.この表ー4の電極 間電気抵抗は, しゃ水シート上下の電極の長さが, しゃ水シートの上側と下側で $9 \mathrm{~m}$ と $19 \mathrm{~m}$ と異なる ため, 電極 $10 \mathrm{~m}$ 当たりに換算した電気抵抗である.

E P D MおよびP V Cしゃ水シートを敷設した土 槽の電極間電気抵抗を比較すると, E P D L ゃ 水シートを敷設した土槽の電極間電気抵抗が $\mathrm{P} V$ Cしゃ水シートを敷設した土槽の電極間電気抵抗 よりもいずれも小さいことがわかる. 特にしゃ水 シート下側の電極間電気抵抗の差が顕著である. 

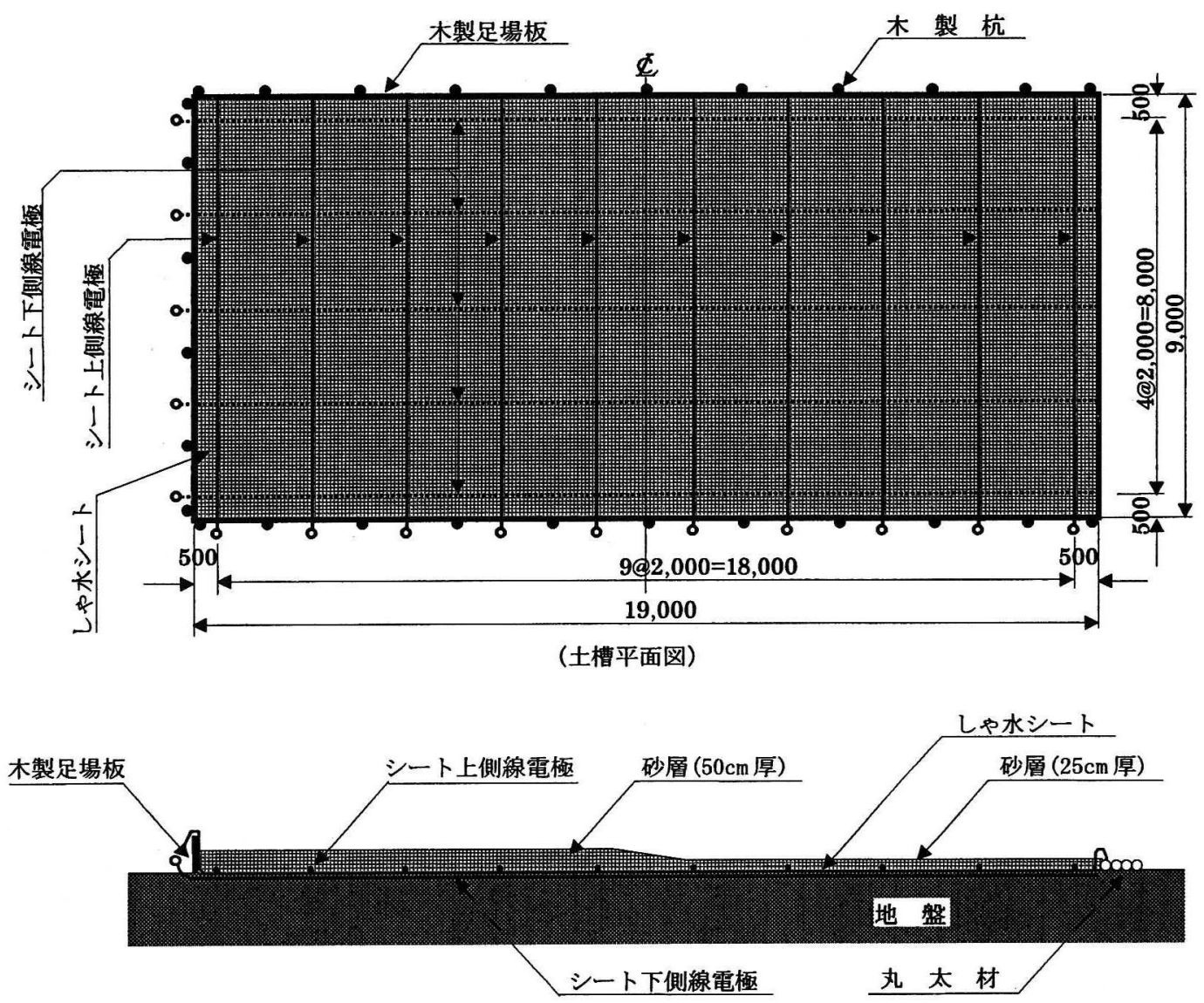

（土槽断面図）

图－5 実験用土槽

表一3 土槽の砂層の含水比

\begin{tabular}{|c|c|c|}
\hline 試 料 & $\begin{array}{c}\text { E P D } \\
(\%)\end{array}$ & $\begin{array}{c}\text { P V C } \\
(\%)\end{array}$ \\
\hline 1 & 5.50 & 5.57 \\
\hline 2 & 5.91 & 5.68 \\
\hline 3 & 5.85 & 5.98 \\
\hline 平 均 & 5.75 & 5.74 \\
\hline
\end{tabular}

ところで, P V Cしや水シートの電気抵抗は, 前述のように非常に高く, ほぼ無限大と仮定して よいと考えられる.この仮定に基づくと， P V C しゃ水シートを敷設した土槽に設置したしゃ水シ 一ト上下の線電極間の電気抵抗は, 砂層の電気抵 抗が $162 \Omega / 10 \mathrm{~m}$ および地盤の電気抵抗が $620 \Omega$ $/ 10 \mathrm{~m}$ と見なせる.

すなわち，P V Cしゃ水シートを敷設した土槽 と E P DMしや水シートを敷設した土槽において,
表ー4 しゃ水シート上下の電極間電気抵抗

\begin{tabular}{|l|c|c|}
\hline シートの種類 & $\begin{array}{c}\text { E P DM } \\
(\Omega / 10 \mathrm{~m})\end{array}$ & $\begin{array}{c}\text { P V C } \\
(\Omega / 10 \mathrm{~m})\end{array}$ \\
\hline シート上側 & 142 & 162 \\
\hline シート下側 & 194 & 620 \\
\hline
\end{tabular}

しゃ水シート上下の電極間抵抗の違いは敷設され たしや水シートの電気抵抗の違いによって生じた ものと考えられる.ここで，EPDMしゃ水シー トの地盤側と砂層側の $10 \mathrm{~m}$ 幅あたりの電気抵抗を それぞれ $r_{D}, r_{G}$ とする. 電極間電気抵抗は, 地盤 もしくは砂層の電気抵抗としや水シートの電気抵 抗との合成電気抵抗であるから，以下の式(8)と 式 (9) が成り立つ.それぞれの式を解くことによ り, E P D L しゃ水シートの $10 \mathrm{~m}$ 幅当たり電気抵 


\begin{tabular}{|} 
表-5 シート接合部周辺の電極間電気抵抗 \\
\hline 測定条件 & $\begin{array}{c}\text { 電気抵抗 } \\
(\mathrm{M} \Omega / 4 \mathrm{~cm})\end{array}$ \\
\hline $\begin{array}{c}\text { 接合部に平行 } \\
1\end{array}$ & 0.6 \\
\hline $\begin{array}{c}\text { 接合部に垂直 } \\
2\end{array}$ & 3.0 \\
\hline 接合部 $※ 3$ & 120 \\
\hline
\end{tabular}

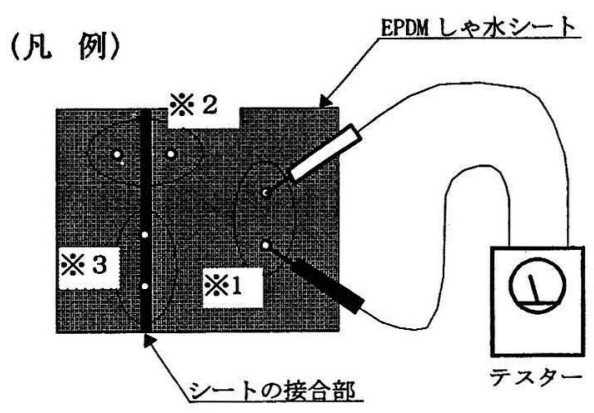

抗は, 地盤側が $282 \Omega / 10 \mathrm{~m}$, 土槽の砂層側が 1150 $\Omega / 10 \mathrm{~m}$ の值が得られる.

（しや水シート地盤側の電気抵抗）

$$
\begin{aligned}
& \frac{1}{\frac{1}{r_{D}}+\frac{1}{162}}=\frac{1}{142} \\
& r_{D}=1150 \Omega / 10 \mathrm{~m}
\end{aligned}
$$

（しや水シート砂層側の電気抵抗）

$$
\begin{aligned}
& \frac{1}{\frac{1}{r_{G}}+\frac{1}{620}}=\frac{1}{194} \\
& r_{G}=282 \Omega / 10 \mathrm{~m}
\end{aligned}
$$

以上の実験から, A 社のE P D Mしゃ水シート の電気抵抗は, しゃ水シート接合方向に地盤の電 気抵抗の $45 \%(=100 \times 282 / 620)$ しかなく, しゃ 水シ一トの接合部の直交方向に地盤の電気抵抗の 約 1.9 倍（=1150/620）でしかないことがわる.

\section{（3）EPDMLゃ水シートの電気抵抗の特性}

（2）で述べたように，しゃ水シートの地盤側 と土槽側ではしや水シートの $10 \mathrm{~m}$ 幅当たりの電気 抵抗が異なる。この理由は, E P D L ゃ水シー トの製造方法に起因すると考えられる.

すなわち，土槽に敷設したしゃ水シートは，電 気的特性が均一な 1 枚ものとして製造されてい

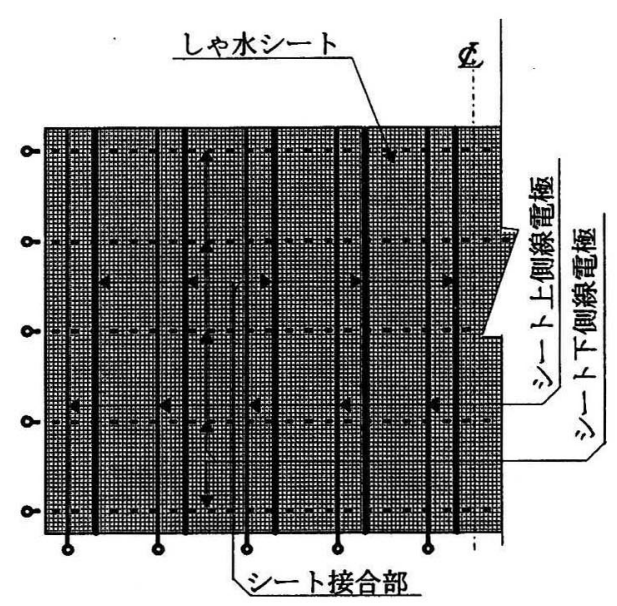

図ー6 測定電極とシート接合部の位置関係

るわけではなく, 図一6に示すように土槽の短手 方向に約 $2 \mathrm{~m}$ 幅のしゃ水シート反物の重ね合わせ 部に非加硫ゴム接着材 (ブチルゴム) を挿入して 熱加硫により接合して製造されている.

このしゃ水シート接合部周辺の電気抵抗を直流 テスターで計測すると, E P D L や水シートは, 表一 5 に示すようにしゃ水シート接合部の方向に 電気抵抗が小さく, 接合部に対して直交方向に電 気抵抗が大きい性質を有していることがわかる．

さらに接着材として使用されている非加硫ゴム （ブチルゴム）の特性を調べるため, 非加硫ゴム をしや水シート状に加工し，しゃ水シートの電気 特性を試験したところ, 表一 1 の接着材の項に示 すように非常に高い絶縁性を有しており，これに よってしや水シートを構成している反物の方向に 電気が通りやくすく, 接合部の直交方法に電気が 通りにくくなっていると考えられる.

\section{5.しや水シートによる測定障害例}

A 社のE P DMしゃ水シートを敷設した土槽に おいて観察された電気的漏水位置検知の測定障害 の例を示す. 実験は, 図一 5 に示す土槽を使用し, 電流測定と線電極を特徽とする電気的漏水位置検 知システムにより行った.この実験に使用した電 気的漏水位置検知システム ${ }^{16)}$ の測定原理と性能は, 大型模型実験結果により実証されている.

前述のように, 土槽は隣接した位置に 2 つ造成 し, それぞれの土槽に $1.5 \mathrm{~mm}$ 厚のE P D L ゃ水 シートと P V C しゃ水シートを敷設し, しや水シ 


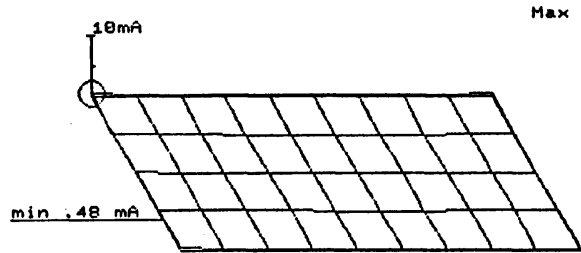

図ー7 実験開始前の测定結果 (PV C)

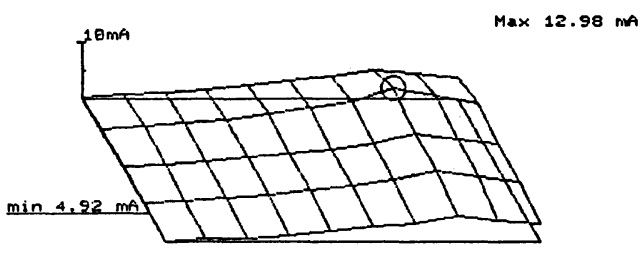

図－9 シート破損後の測定結果（PV C)

一ト上には $25 \mathrm{~cm}$ と $50 \mathrm{~cm}$ 厚の砂層を設けた.この 砂層上で $23 \mathrm{t}$ 級ブルドーザの走行および方向転換 を実施し, その前後で漏水検知システムによる測 定を行った。

図－7〜図-10に示す測定結果は，図一5 の実 験土槽のしゃ水シート上下の線電極が交差する点 について, 印加電圧と同じ位相をもつ電流につい て 3 次元で図示したもので, 大きな電流が流れて いる箇所が漏水位置を示す. 図一 7 と図ー8 は, ブルドーザ走行前の各土槽の測定結果を示したも のである.図ー7は，PVCしゃ水シートを敷設 した土槽の測定結果であるが，最大でも $0.95 \mathrm{~mA}$ の電流しか流れない非常に均一な測定結果となっ ている. それに対して，図－8に示すE P DMし や水シートを教設した土槽の測定結果は, しゃ水 シートに損傷がない状態であるにもかかわらず, 最大 $59.24 \mathrm{~mA}$ 最小 $30.74 \mathrm{~mA}$ の電流が流れており， 電流の大きさも説明不能な傾向がみられる.この 最大電流が測定された部分について砂層を除去し てしゃ水シートの状態を調查したが, しゃ水シー トの損傷とみられる籄所はまったく発見できなか った. 一方, P V Cしゃ水シートが破損した直後 の測定結果は, 図一 9 中の○印に示すように損傷 が生じた部分で最大電流 $12.98 \mathrm{~mA}$ の明確なピーク が認められる. また，E P D M や水シートを敷 設した土槽の場合, 図一8の初期状態と比較する

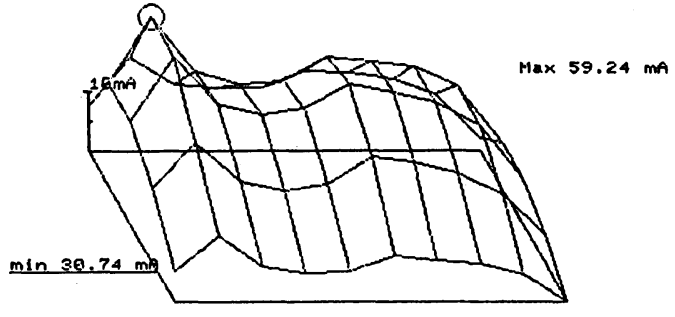

图-8 実験開始前の測定結果（E P DM）

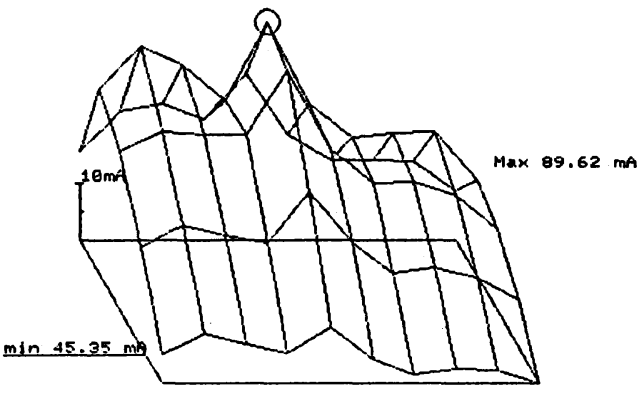

図-10 シート破損後の測定結果（E P DM）

と新たな明確なピーク $89.62 \mathrm{~mA}$ が認められるが, この箇所の相当部分に損甥は存在したが, この他 にも多くの損傷が砂層の撤去後確認でき, この測 定から得られた結果を論理的に説明することはで きない。

測定障害が認められられたE P DMしや水シー トを敷設した土槽と良好な測定結果が得られた $\mathrm{P}$ V Cしゃ水シートを敷設した土槽において，損傷 の発生の前後で確認された電流の最大值の変化を 比較すると, P V C しゃ水シートの場合 13.7 倍 (=12.98/0.95) であるのに対して, E P DMし や水シートの場合 1.51 倍（=89.62/59.24）にす ぎない.これは，PVCしゃ水シートとE P D M しゃ水シートの電気抵抗の違いによって生じた現 象と考えられる.すなわち，PV Cしゃ水シート の電気抵抗は，表一 1 に示したように $120 \mathrm{~cm}^{2}$ あた り $10 \mathrm{M} \Omega$ 以上と非常に大きい。 これに対して， $\mathrm{E}$ PDMしゃ水シートの電気抵抗は P V C しゃ水シ 一トの電気抵抗と比較して, 测定電極表面が乾燥 した状態にあっても， $120 \mathrm{~cm}^{2}$ あたり $8.5 \times 10^{-2} \mathrm{M}$ $\Omega$ と非常に小さい。したがって，E P DMしゃ水 シートが敷設された土槽において，図一 4 に示し たようにしや水シートを流れる回路の電気抵抗が もともと小さいため, しゃ水シートを介して流れ る電流が損傷発生前から大きく, 損傷の発生によ る電流増加の比率が小さいものと判断される。一 
方，電気抵抗が大きい P V Cしゃ水シートを敷設 した土槽の測定では, しゃ水シートの損傷発生後 はじめて図ー3に示す漏水を経由する回路ができ， 漏水発生前後における電流変化の比率が大きくな るものと考えられる.

\section{6. 考察}

前章までに述べたしゃ水シートの電気特性に関 する実験と土槽を使用して行った実験で生じた測 定障害から, 各種電気的漏水検知方法のしゃ水シ 一トの電気抵抗から受ける影響について考察する.

\section{（1）測定原理への影留}

既往の電気的漏水位置検知方法の研究において 述べたように，電位を測定する方法と電流を测定 する方法と電気抵抗の分布を測定する方法に大別 できる。

前述の測定障害は, 電流測定による漏水位置検 知方法の測定結果に生じた.こうした測定障害は, 電位測定や電気抵抗測定による漏水位置検知方法 においても生ずると考えられる.

すなわち，電位差測定による漏水位置検知方法

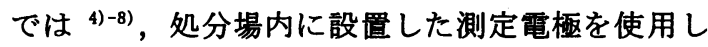
て電位測定を行い, 処分場内の電位分布をもとめ, 電位分布の異常から漏水位置を特定する. しかし, この測定方法が成功する前提として，処分場内外 が大きな電気抵抗のしゃ水シートで電気的にしゃ 断された条件でなければならない.しゃ水シート がこの条件を満たせば, 漏水の周辺に大きな電位 異常が生じ, 容易に漏水位置を特定することがで きる. しかし，しゃ水シートの電気抵抗が小さい 場合, しゃ水シートを介して流れる電流により生 ずる電界で，漏水周辺に生ずる電位異常の検知が 困難となる. 特に, しや水シートの電気抵抗が地 盤の電気抵抗よりも小さい場合には，漏水位置を 検知することは不可能と考えられる.

また，EPDMしや水シートのように，反物の 接合部分の電気抵抗が大きくシート素材自体の電 気抵抗が小さい場合，接合部の方向とその直交方 向の電気抵抗の特性が完全に異なる. したがって, このような特性のしゃ水シートが敷設された処分 場の場合, 処分場内に設置した印加電極周辺の電 界がしや水シートの特性により大きくゆがめられ， 漏水による電位異常かしや水シートの特性による ものか判別が非常に困難となると考えられる.

同様の理由により，電位傾度法を応用した漏水

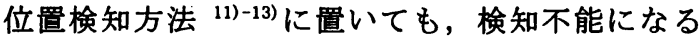
と考えられる.

一方, 電気抵抗測定による漏水位置検知方法に は, しゃ水シート上下に設置した電極閒の電気抵 抗 (インピーダンス) を測定する方法 ${ }^{14)}$ と, 2 重 しゃ水シートの排水層内に設置した 2 本の裸電線 間の電気抵抗を測定する方法 ${ }^{9), 10)}$ がある. しゃ水 シート上下に設置した電極間の電気抵抗を測定す る方法では, 前述の電流測定による方法と同様に しゃ水シートを経由する回路が生じ, 漏水を経由 する回路の電気抵抗だけ取り出して計測できず, 漏水位置の検知が非常に困難もしくは不可能とな る.

したがって，地盤よりもしや水シートの電気抵 抗の方が小さい場合, いずれの電気的漏水位置検 知方法も, 漏水の位膡検知は不可能となると考え られる。

筆者らが実施した一連の実験は, しゃ水シート を非常に乾燥した地盤面に敷設して実施されたも のあり，特殊な条件とも考えられる．しかし，寒 際の処分場においても, 地下水位が低く空隙が多 い砂磷層地盤では, 雨水の浸透がしや水シートの ために抑制され，しゃ水シートの電気抵抗が地盤 よりも小さくなる可能性が十分考えられる.

ところで, しゃ水シートを介して流れる電流は, 電気的漏水位置検知において実際の漏水とは無関 係のノイズでしかなく, 漏水を経由して流れる電 流と分離することはできない. したがって, 処分 場に敷設するしゃ水シートの電気抵抗は，できる だけ大きい（120 $\mathrm{cm}^{2}$ あり $10 \mathrm{M} \Omega$ 以上）方が測定 精度望ましい考えられる。

\section{(2) 電極方式への影斐}

現在までに開発されたの電気的漏水位置検知方 法のうち, 処分場内に点電極を多数設置する方法 が多いが，裸電線を配置することにより少数の電 極で広い面積をカバーできる線電極の利用が研究 されている.

電位測定, 電流測定, 電気抵抗測定を測定原理 とするそれぞれの方法とも，E P D Lしゃ水シー トのようにしや水シート表裹間の電気抵抗が低い しゃ水シートが敷設された処分場では, 測定原理 上漏水位置検知が非常に困難となることは既に示 した.

一方, 表一 1 と表一 2 に示した導電性H D P E のようにしや水シートの片面のみ電気抵抗が小さ い場合, しや水シート表裏間の電気抵抗は P V C しゃ水シートや通常のHD P E しや水シートなら 
びに融着ゴムしゃ水シートのように，非常に電気 抵抗が大きい。したがって，しや水シート接合部 分を電気的に十分絶縁すれば, 漏水位膡検知は処 分場内部だけに点電極を配膡する検知方法であれ ば十分可能と考えられる.

しかし，2 重しゃ水シート内に配置された 2 本 の線電極間の抵抗を測定することにより漏水位置 を特定する方法 ${ }^{9), 10)}$ では，しゃ水シートの電気抵 抗が大きい場合には漏水から流入した浸出水で濡 れた排水層によって形成される 2 本の線電極間を つなぐ回路が限定され, 漏水位置が検知できると 考えられるが，しゃ水シートの電気抵抗が小さい 場合には電極から電極までの電気回路が不織布な ど排水層だけでなく，しゃ水シート全体に拡がる ため, 漏水位置は検知できないと考えられる.

また，線電極を使用する電位測定による漏水位 置検知方法 ${ }^{8)}$ でも，導電性を有する側に配置した 電極がすべて同電位となるため，漏水位置は検知 できないと考えられる.

線電極を用いる漏水位置検知方法は, 点電極を 使用する漏水位置検知方法と比較して, 少数の電 極で広い面積をカバーできるため，広大な処分場 の場合测定システムの建設コストで比較して非常 に有利な面が多い，しかし，片面の電気抵抗を小 さくしたしゃ水シートに線電極の適用は不可能と 考えられる.

\section{7. 結論}

以上の実験結果から，本研究で判明した結論を 述べる。

1）EPDMしゃ水シートの製品の中には，非常に 電気抵抗が小さくかつ静電容量が大きいものが あり，電極としや水シート表面が湿潤状態とな って電気的接触条件が改善されると,さらに電 気抵抗が小さく静電容量も大きくなる.

2)一般にP V C しゃ水シートやHD P E しや水シ 一トおよび融着ゴム製しや水シートの電気抵抗 は非常に高く, 静電容量もE P D M ゃ水シー トと比較すると $1 / 1000$ 程度で, しゃ水シート 試験片表面に接触させた電極面が湿潤状態もし くは乾燥状態であっても電気特性の変化は小さ い.

3)電気抵抗が大きいHD P Eであっても，カーボ ンブラック含有量により電気抵抗が小さいしゃ 水シートも存在する. しや水シートの片面のみ 電気抵抗を小さくしたHD P Eしゃ水シートは,
しゃ水シート表裹間の電気抵抗が一般のしゃ水 シートと同様に非常に大きく，接合部の絶縁処 理が完全であれば，点電極の漏水位贯検知方法 が適用できる.

4) 導電性の高いしゃ水シートの接合に電気抵抗が 大きい接着剤が使用された場合，しゃ水シート の接合部方向に電気抵抗が小さく，接合部の直 交方向に電気抵抗が大きい特性が加わる.

5)地盤よりも電気抵抗が小さいしゃ水シートが敷 設されると，点電極ならびに線電極を使用する 電気的漏水位置検知システムとも漏水を検知で きない.

6)線電極を使用する電気的漏水位置検知方法では, 電気抵抗が小さいしゃ水シートや片面のみ電気 抵抗を小さくしたしや水シートが教設された条 件では適用できない.

最近になって，電気的漏水位置検知システムを 処分場に導入するケースが増えている.こうした， 電気的漏水位置検知システムを導入する場合, 事 前にしゃ水シートの電気特性の検討が不可欠であ る. しゃ水シートの電気抵抗が小さい場合，しゃ 水シートの漏水位置検知が非常に困難となる。本 論文では，EＰＤしゃ水シートが有する小さな 電気抵抗によって生じた測定障害例を示したが， このようなしゃ水シートの特性に関連した測定障 害は, 事前のしゃ水シートの電気特性について詳 細な検討により防止できるはずである.

電気的漏水位置検知システムの原理面や実用化 の研究は今後とも重要であるが，しや水シートの 詳細な電気特性の把握も重要と考えられる.

謝辞 : 本研究にあたっては，（株）レイディック 坂田所長にご協力を頂き，ここに謝意を表します.

\section{参考文献}

1) Gross, B.A., Bonaparte, R. and Giroud, J.P.: Evaluation of flow from landfill leakage detenction layers, Proc. of the 4th International Conference on Geotexitiles Geomembranes and Related Products, Vol. 2, pp.481 - 486,1990.

2) Koener,R.M. :Design with Geosynthetics, 3rd ed., Prentice-Hall Inc., pp.529 - 542, 1994.

3）小谷克己, 串間正敏, 虾和夫, 黒岩正夫, 前田章, 鍺方浩基 : しや水シートの真空管理システムの実 験報告, 第 4 回廃棄物研究発表会講演論文集, pp. 491 - 494, 1993.

4) Schultz, D.W., Duff, B.M. and Peters, W.R. : Performance of an Electrical Resistivity 
Technique for Detecting and Locating Geomembrane Failures, Report No. EPA600/D-84-123, 1984.

5）野口康治，押方利郎，川上純，臼井直人，金子伯 男 : 電気探查を用いた管理型最終処分場の漏水位 置検知方法ーモデル実験結果, 物理探查学会第 79 回学術講演会講演論文集, pp. $211-212,1988$.

6）古市徽, 田中勝, 押方利郎, 海老原正明：埋立 処分場監視システムの開発要因に関する考察，第 5 回廃棄物研究発表会講演論文集, pp. $369-372$, 1994.

7）島裕雅，奥村興平，大橋英隆，本徳修三，福岡晃 一郎： 管理型廃乗物処分場における漏油電流評 価法による高精度漏水探查, 第 5 回廃衰物研究 発表会講演論文集, pp. 383 - 385, 1994.

8）土弘道夫, 瀬尾昭治, 末吉隆信, 浦满彦, 若林秀 楜, 広野進: 廃棄物処分場におけるしや水シート の漏水検知システムの開発, 第 5 回廃棄物研究 発表会講演論文集, pp. 605 - 607, 1995.

9) Meerleer, F. de : Accurate Detection and Location of Effluent Leaks Beneath Lined Waste Disposal Sites, Proc. of the 5th International Conference on Geotextiles, Geomembranes and Related Products, Vol.3, pp.913 - 918, 1994.

10）大野文良, 佐々木润治, 桜井仁 : 最終処分場にお ける漏水検知システム (パルス法) の開発，第 7 回廃棄物研究発表会講演論文集, pp. 656 - 657, 1996.

11) Landreth,R.E. :Locating and Repairing Leaks in Landfill/ Impoundment Flexible Membrane
Liners, Report No. EPA/600/D-88/183, Aug. 1988.

12) Darilek,G.T. and Para,J.O.: The Electrical Leak Location Method for Geomembrane Liners, Report No. EPA/600/2-88/035, Jun. 1988.

13）荒井健, 新井斉, 山崎宣悦, 大即信明: 差動回路 で測定した電位差による廃棄物処分場の漏水位置 検知方法, 土木学会論文集, No. $602 / \mathrm{VI}-40$, pp. 75 - 91, 1998.

14）西山勝栄, 伊藤洋, 木内幸則, 近藤三樹郎：面電 極法によるしゃ水シートの漏水位置検知システム の開発, 第 7 回廃衰物研究発表会講演論文集, pp. $648-650,1996$.

15）荒井健, 新井斉, 山崎宜悦, 波多野雅一郎：廃萧 物処分場の漏水位置検出方法, 物理探查学会第 86 回学術講演会講演論文集, pp. $390-395,1992$.

16）荒井健：管理型終末処理場の漏水位置検知方法の 開発, 物理探查学会第 81 回学術講演会講演論文 集, pp. $236-241,1989$.

17）物理探鉱技術協会編:物理探查用語辞典, 物理探 鉱技術協会, pp. $105-106 ， 1979$.

18）物理探鉱技術協会編：物理探查用語辞典，物理探 鉱技術協会, pp. 244, 1979 .

19）阿部善右衛門，木下敏夫: 計測回路， pp. 188-190, 朝倉書店, 1980 .

20) 西巻正郎: 電気学, 森北出版, pp. 78-92, 1975

21）大石進一:フーリエ解析，岩波書店， 1989.

22）物理探釷技術協会編:物理探查用語辞典, 物理探 鉱技術協会, pp. $233-234,1979$.

(1998.5.1 受付)

\title{
THE INFLUENCE OF ELECTRIC PROPERTIES OF GEOMEMBRANE ON ELECTRICAL LEAK DETECTION FOR LANDFILL SITES
}

\author{
Ken ARAI, Hitoshi ARAI, Nobuyoshi YAMAZAKI and Nobuaki OTSUKI
}

Many electrical leak detection methods have been researched and developed, in many laboratories, for landfill site lined with geomembrane such as synthetic rubber and plastics. The methods assume that the geomembrane has a high electrical resistance and the points of leakage are searched out and detected by mesuring differences in electrical potential, current or electrical resistivity. The authors of this paper have investigated the electrical properties of various membranes, and have found that some geomembranes are not electrical insulators and therefore the traditional theory that they should be insulators no longer holds good. This paper presents the electrical structure within a landfill site, the electrical properties of various geomembranes and the influence of geomembranes with a low electrical resistivity on electrical leak detection. 